\title{
The relationship between methane migration and shale-gas well operations near Dimock, Pennsylvania, USA
}

\author{
Patrick A. Hammond ${ }^{1}$
}

Received: 14 April 2015 / Accepted: 21 October 2015 /Published online: 10 November 2015

(C) The Author(s) 2015. This article is published with open access at Springerlink.com

\begin{abstract}
Migration of stray methane gas near the town of Dimock, Pennsylvania, has been at the center of the debate on the safety of shale gas drilling and hydraulic fracturing in the United States. The presented study relates temporal variations in molecular concentrations and stable isotope compositions of methane and ethane to shale-gas well activity (i.e., vertical/horizontal drilling, hydraulic fracturing and remedial actions). This was accomplished by analyzing data collected, between 2008 and 2012, by state and federal agencies and the gas well operator. In some cases, methane migration started prior to hydraulic fracturing. Methane levels of contaminated water wells sampled were one to several orders of magnitude greater than the concentrations due to natural variation in water wells of the local area. Isotope analyses indicate that all samples had a thermogenic origin at varying maturity levels, but from formations above the hydraulically fractured Marcellus Shale. The results from the initial water well samples were similar to annular gas values, but not those of production gases. This indicates that leakage by casing cement seals most likely caused the impacts, not breaks in the production casing walls. Remediation by squeeze cementing was partially effective in mitigating impacts of gas migration. In several cases where remediation caused a substantial reduction in methane levels, there were also substantial changes in the isotope values, providing evidence of two sources, one
\end{abstract}

Electronic supplementary material The online version of this article (doi:10.1007/s10040-015-1332-4) contains supplementary material, which is available to authorized users.

Patrick A. Hammond

phammond@broadstripe.net

1 Maryland Department of the Environment (Retired), 41 Marnel Court, Severna Park, MD 21146, USA natural and the other man-induced. Sampling water wells while venting gas wells appears to be a cost-effective method for determining if methane migration has occurred.

Keywords Groundwater monitoring · Methane migration · Hydraulic fracturing $\cdot$ Marcellus Shale $\cdot$ USA

\section{Introduction}

Dimock, a small town in Susquehanna County, northeastern Pennsylvania (USA), received national and international attention due to much publicized incidents of methane contamination of water wells, just outside of town in 2009, which were featured in the 2010 Gasland and 2013 Gasland 2 movies on HBO. Some environmental groups have related the methane migration to directional drilling and hydraulic fracturing of gas shale wells, while some industry-related studies indicate that the methane occurred naturally. The Pennsylvania Department of Environmental Protection (PA DEP) conducted an investigation into the problem and entered into a consent order with the operator in December 2009 that required remediation of certain shale-gas wells and mitigation for the residents having affected water supplies. In December 2010, a Consent Order and Settlement Agreement was reached which included a financial settlement for 19 residents in the Dimock area. In addition to high methane concentrations, there was some evidence of contamination by other chemical compounds. This led the United Sates Environmental Protection Agency (US EPA) to conducted extensive sampling and analysis of water from the affected and other nearby water wells in early 2012 (US EPA 2012).

Osborn et al. (2011) presented evidence that methane contamination of drinking water was associated with shale gas extraction in aquifers overlying the Marcellus and Utica shale 
formations of northeastern Pennsylvania and upstate New York. Average and maximum methane concentrations in 26 drinking-water wells within $1 \mathrm{~km}$ of the nearest gas well (active areas) were 19.2 and $64 \mathrm{mg} / \mathrm{L}$, respectively, while dissolved methane samples from 34 wells where there were no gas wells within $1 \mathrm{~km}$ (non-active areas) averaged only $1.1 \mathrm{mg} / \mathrm{L}$. About half of the total number of samples were collected in the Dimock area. Osborn et al. (2011) proposed three possible gas migration mechanisms. They indicated the most likely one was leakage through gas-well casings. A second one that they considered unlikely was the physical displacement of gas-rich solution through overlying strata that could be $1-2 \mathrm{~km}$ thick. The third was by hydraulic stimulation of new or existing fractures, providing a vertical connection between deep formations and shallow aquifers, especially in the presence of older, uncased and abandoned gas wells. No evidence of contamination of drinking water supplies by fluids used for drilling or hydraulic fracturing was found in that study. Jackson et al. (2013) analyzed samples from 141 drinking water wells: 81 new wells plus the 60 from the Osborn et al. (2011) study. Methane was detected in $82 \%$ of drinking water samples, with average concentrations six times higher for homes $<1 \mathrm{~km}$ from natural gas wells. Ethane was 23 times higher in homes $<1 \mathrm{~km}$ from gas wells and propane was detected in 10 water wells within approximately $1 \mathrm{~km}$ distance. Distance to gas wells was highly significant for methane concentrations, whereas distances to valley bottoms and the Appalachian Structural Front were not significant.

Molofsky et al. (2011) analyzed samples taken from more than 1,700 "pre-drill" samples in south central Susquehanna County, including about 170 in the Dimock Township. They indicated that methane was ubiquitous in the shallow groundwater, although the average concentration of the 1,700 water samples was $0.7 \mathrm{mg} / \mathrm{L}$, while $3 \%$ and only $0.2 \%$ exceeded the unsafe levels of 10 and $28 \mathrm{mg} / \mathrm{L}$, respectively. The basis for the hazard limits is discussed in Eltschlager et al. (2001). Molofsky et al. (2011) further stated that there was a clear correlation between methane concentrations and surface topography, in that dissolved gas levels were significantly higher in wells in lowland areas than in upland locations, and there was no relation with proximity to existing gas wells. Molofsky et al. (2013) republished the results of the testing of the 1,701 water wells, of which 1,379 were considered to be in pre-drill or "nonproduction areas". They corrected some of the locational data and changed the source of the hydrocarbon gases present in Dimock water wells from the shallow Catskill Formation to the deeper Middle Devonian Mahantango Formation, just above the Marcellus Shale.

In Jan-Mar 2012, the US EPA collected samples from 59 house wells in the Dimock area for methane and ethane analyses. The methane concentrations were $\geq 3 \mathrm{mg} / \mathrm{L}$ in $23 \mathrm{sam}$ ples (39\%), $\geq 10 \mathrm{mg} / \mathrm{L}$ in 17 samples $(29 \%$ ) and $\geq 28 \mathrm{mg} / \mathrm{L}$ in
5 samples $(8.5 \%)$, while the average of the 59 wells was $9.0 \mathrm{mg} / \mathrm{L}$.

While great amounts of data were collected, and several peer-reviewed studies and other reports have been published, none of the investigations have attempted to directly relate the potential methane migration to discrete gas well activities.

\section{Methods}

\section{Data sources and acquisition}

The purpose of the present investigation was to determine if a reasonable assessment could be made concerning how gas well operations may have affected the migration of methane and contamination of the Dimock area water wells.

This involved collecting and analyzing all the published and other publically available data concerning the following types of information:

1. Shale-gas and water well construction characteristics

2. Regional and local geology related to structural, stratigraphic and surficial features

3. Methane and ethane concentrations and isotopic characteristics of local gas and water wells

4. A review of regional studies concerning methane distribution in water wells relative to their topographic position and proximity to operating gas wells

5. Reports and other information regarding gas well activity such as, spud, completion and stimulation dates, pressure measurements, casing and cement histories, and records of remedial squeeze cementing and plugging of gas wells

6. Reports of efforts to mitigate potential impacts to affected water wells

7. Proximity of shale-gas and water wells to sites with potentially anaerobic and aerobic soils

8. Mechanisms other than gas well activity that might affect methane distribution

Molecular and isotopic analyses of gases in shale-gas wells and local water wells in the Dimock Township were collected during the stray gas investigation conducted by the PA DEP and the operator between 2009 and 2011, using procedures described in the supporting information of Molofsky et al. (2013). The present study also reviews molecular and isotopic data from dissolved gases in water wells collected by Osborn et al. (2011) and the US EPA (2012); details of the sample collection and analyses are presented in those respective studies.

Each of the aforementioned studies used different methods for identifying locations of shale-gas and water wells, which required a substantial effort to correlate data collected from individual wells. The PA DEP and the operator listed wells by 
the name of the operator or home owner. In 2009, PA DEP prepared a map of the private wells and the operator constructed one for the gas wells, Damascus Citizens for Sustainability (2009). The operator followed in 2011 with detailed maps including all gas and water wells in the area, Cabot Oil and Gas Corporation (2011). Osborn et al. (2011) provided a small-scale map annotated with wells; but the chemical data could not be tied to individual well locations. Molofsky et al. (2011) provided maps with well numbers, but included no names, and the locations had to be corrected in the Molofsky et al. (2013) paper. The US EPA data set included well numbers but no locations; however, an internal report provided some limited locational data. The water quality data contained in the Osborn et al. (2011) and Jackson et al. (2013) studies could not be directly related to the other investigations, except that the isotopic results for the samples collected in the Dimock area are similar to those of the US EPA (2012). The identification systems used by the US EPA (2012) and Molofsky et al. $(2011,2013)$ appear to be designed to protect the privacy of the individual home owners or, in the case of the US EPA, as part of a blind test; so an alpha-numeric notation is used in the present study to maintain anonymity. Shale-gas well locations were obtained from the PA Oil and Gas Mapping Website (PA DEP 2009).

The ideal scenario for demonstrating potential impacts of gas well extraction to the water supply wells would have been to collect background information, then measure changes in the chemical properties over time after the start of gas well operations. In the case of the Dimock-area wells along Carter Road, there were no background data collected, except for pre-drill LEL measurements of methane levels taken in 12 domestic wells. Due to efforts by the operator to remediate the impacts caused by the gas wells, there were recovery phases at the various well sites similar to that which occurs during interference testing of gas wells by the release of pressure in gas wells or in water supply wells by the cessation of pumping. The cross correlation between the data from the various studies was critical for establishing a timeline for relating changes in methane and ethane concentrations and isotopic parameters to shale-gas well activity.

\section{Factors potentially affecting methane migration}

Watson (2010) provided a detailed description of the completion and plugging activities for many of the operator's wells. A presentation by the operator to PA DEP, Cabot Oil and Gas Corporation (2011), provided detailed site location maps, including names of homeowners and gas well pad/identification numbers, which were very useful in clarifying what data came from each water and gas well. That presentation also included detailed results of molar concentrations of methane and other compounds that updated previous reports, as well as additional information on remedial actions taken for the gas wells, including pressure testing, and mitigation efforts related to homeowner impacts. Other information concerning gas well operations, methane chemistry and water well data were obtained by Pennsylvania Right-To-Know (RTK) Law requests (James E. Miller, PA DEP, RTK requests, unpublished, Table 1).

Whiticar (1999) described the various pathways by which methane is generated. In shallow, marine sediments, low levels of methane are produced by sulphate reduction. Once the available dissolved sulphate is exhausted, usually at greater sediment depths, carbonate reduction is the dominant pathway for generation of methane. Methanogenesis proceeds uninhibited in freshwater, low sulphate environments, primarily by acetate fermentation, once anaerobic conditions are established. Bacterial oxidation of migrating gases can produce decreased methane concentrations, with enrichment of heavy stable isotope ratios, which is the process of kinetic fractionation. The degree of fractionation depends on the proportion of migrated to biogenic gas. Also, physical mixing of methane from different sources due to vertical or lateral migration of gas can produce mixtures of thermogenic gas and bacterial generated gas or other thermogenic gas.

Le Mer and Roger (2001) indicated that methane is primarily produced in the anaerobic zones of submerged wetlands soils by methanogens and is oxidized into $\mathrm{CO}_{2}$ by methanotrophs in the aerobic zones of wetland soils, as well as in upland soils. Methane consumption is highest in cultivated or natural wetlands where methanogenesis is or has been effective, and where $\mathrm{CH}_{4}$ concentration is or has been much higher than in the atmosphere. Factors that favor $\mathrm{CH}_{4}$ emission from cultivated wetlands are mostly submersion and organic matter addition. Intermittent drainage and utilization of the sulphate forms of $\mathrm{N}$-fertilizers reduce $\mathrm{CH}_{4}$ emission. Aerobic soils consume atmospheric $\mathrm{CH}_{4}$, but their activities are very low and the micro-organisms involved are largely unknown. Forest soils are the most active, followed by grasslands and cultivated soils. Methane oxidation potential of upland soils is reduced by cultivation, especially by ammonium $\mathrm{N}$-fertilizer application.

Scheutz and Kjeldsen (2004) found that temperature had a strong influence on methanotrophic activity. The optimum temperature was around $30^{\circ} \mathrm{C}$; however, oxidation occurred at temperatures as low as $2{ }^{\circ} \mathrm{C}$. A soil moisture content of $25 \%$ yielded the maximum oxidation rate, as it allowed good gas transport together with sufficient microbial activity. The optimum $\mathrm{pH}$ was around neutrality $(\mathrm{pH} 6.5-7.5)$ showing that the methanotrophs were optimally adapted to the in-situ $\mathrm{pH}$ which was 6.9. Higher ammonium concentrations inhibited the oxidation process.

Concentration gradients may cause methane to flow from higher to lower concentrations or pressures by diffusion. Temperature also affects the solubility of methane, as increasing 
Table 1 PA DEP letter responses to Right-To-Know (RTK) Law record requests

\begin{tabular}{|c|c|c|c|c|}
\hline Name & Year & Date & RTK request number & Records supplied \\
\hline Miller, JE & $2014 \mathrm{a}$ & $6 / 3 / 2014$ & $4400-14-059$ & $\begin{array}{l}\text { 1. Isotopic sample data sheet dated 10/19/2010, Carter Road Gas } \\
\text { Migration, Dimock Twp./Susquehanna County. } \\
\text { 2. PA DEP internal memo RE: Stray gas investigation, Dimock Twp., } \\
\text { produced on } 26 \text { Sept. } 2010 \text { by F. Baldassarre. } \\
\text { 3. Well record and completion reports and, if applicable, certificates } \\
\text { of well plugging for the following gas wells: } \\
\text { Baker } 1 \text { (AP\# 115-20026), Baker 3 (AP\# 115-20226), Gesford 3S } \\
\text { (AP\# 115-20163), Gesford 7H (AP\# 115-20163) and Ratzel } 1 \mathrm{H} \\
\text { (AP\# 115-20047) }\end{array}$ \\
\hline Miller, JE & $2014 b$ & $9 / 4 / 2014$ & $\begin{array}{l}4400-14-095(\mathrm{NC}) \\
4600-14-055(\mathrm{NW})\end{array}$ & $\begin{array}{l}\text { Well record and completion reports for the Ratzel 2H (AP\# 115-20152) } \\
\text { and Ratzel } 3 \text { V (AP\# 115-20117) gas wells }\end{array}$ \\
\hline Miller, JE & $2014 c$ & $9 / 4 / 2014$ & $\begin{array}{l}4400-14-096(\mathrm{NC}) \\
4600-14-056(\mathrm{NW})\end{array}$ & $\begin{array}{l}\text { Well record and completion report, and certificate of well plugging for } \\
\text { the Gesford 3S (37-115-20019-00) gas well, } \pm 6,968 \text { feet total depth }\end{array}$ \\
\hline
\end{tabular}

temperature results in a decrease in solubility. Also, at low temperatures, freezing soils may create a barrier to the vertical migration of methane. Variations in groundwater levels may also cause significant changes in methane levels. Tsunomori and Notsu (2008) monitored gas concentration and groundwater levels in a 500-m open well. The methane concentration in the well showed intermittent spike-like increases during the observation period. The temporal change of the methane concentration was independent of the seismic activity around the station, the groundwater temperature, the ambient temperature, and the pumping rate. The methane concentration varied from 0 to $28 \%$ by volume as groundwater levels declined in response to changes in barometric pressure.

Baldassare et al. (2014) conducted a short-term pumping test $(\sim 2.75 \mathrm{~h})$ of a house well to evaluate groundwater quality and methane concentrations. The pumping rates varied from 3.67 to $14.23 \mathrm{~L} / \mathrm{min}(0.97-3.76 \mathrm{gal} / \mathrm{min})$. At the start of the test there was no detectable combustible gas in the well. After $1.4 \mathrm{~h}$, the onset of free gas occurred at a drawdown of $0.41 \mathrm{~m}$ $(1.35 \mathrm{ft})$. At $2.1 \mathrm{~h}$, there were dissolved-phase methane concentrations of $120 \mathrm{mg} / \mathrm{L}$ and $8.43 \%$ of free gas in the wellbore.

\section{Geology of study area}

The present study relates gas well activity to changes in concentrations and isotopic characteristics of methane and ethane in water wells in the vicinities of Carter Road and Meshoppen Creek Road, about 1 mile southeast of Dimock, Susquehanna County, Pennsylvania, $41.734^{\circ} \mathrm{N},-57.869^{\circ} \mathrm{W}$, Fig. 1 . The surface geology consists of Quaternary alluvial sediments in the stream valleys, glacial till in the valleys and along hillsides, and outcrops of the underlying Catskill formation on hilltops. The Upper Devonian Catskill, Lock Haven and Brailler (Elk) formations consist of interbedded sandstone, siltstone and shale units, Fig. 2. The sandstones of Catskill Formation are the primary aquifer for withdrawals by local water wells. The Bradford sands are a deeper prominent sandstone unit in the Lockhaven Formation. Gas shows are present in Middle Devonian wells, but those formations have not been targets for hydrocarbon exploration. Middle Devonian age units are the Tully Limestone (calcareous shale) and the Hamilton Group, which consists of the Mahantango Formation and the Marcellus Shale. The Mahantango Formation consists of shales, claystones, siltstones, and sandstones. The calcareous Marcellus Shale is the primary source of shale gas exploration in the study area.

\section{Gas well construction and remediation techniques}

The typical Dimock area gas well construction consists of conductor, surface and intermediate casings. Each casing requires a primary cementing operation, i.e., the placement of cement outside the casing in the exterior annulus, providing structural integrity of the wellbore, protecting the steel casing against corrosion, and providing a hydraulic seal to isolate shallow drinking-water aquifers from the underlying production zone. A production casing then extends to the target zone and is usually "open" or uncemented for several thousand feet, until a few hundred feet above the top of the Marcellus Shale. Jackson (2014) indicates that faulty casing and cementing cause most well integrity problems. Casings may leak due to mechanical and chemical failures such as poor pipe connections, well deviation, corrosion, thermal stress, or excessive pressures during drilling, hydraulic fracturing or production. Cracks or channels may form in cement due to chemical reactions, physical impacts or temperature changes. If a casing breaks, leaks or is uncemented, or channels form in a cement seal, then stray methane and other gases may flow upward from intermediate or 
Fig. 1 Geologic map of study area near the town of Dimock, Susquehanna County, Pennsylvania, USA

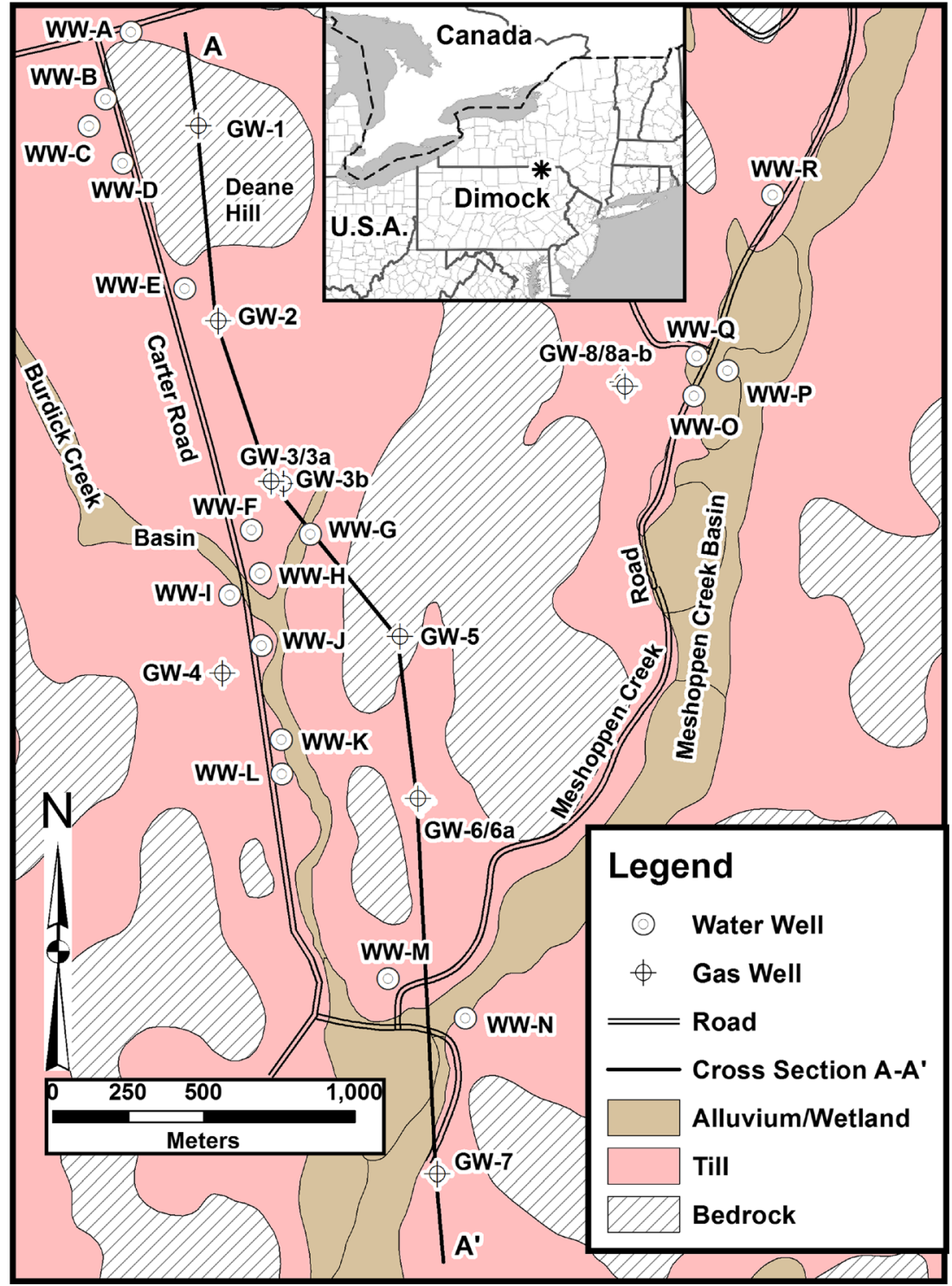

deep layers through the annulus and into shallow drinking-water aquifers. To remediate the problem, a "squeeze" operation is usually performed to fill the void space with a sealing material, typically cement. Holes are blasted in the casing using a perforation gun, the casing is then sealed off and cement under pressure is squeezed through the perforations into the annular region to achieve a suitable seal. Venting of a gas well could also reduce or eliminate methane migration; however, this could lead to undesirable gas emissions to the atmosphere. Corrective methods for water wells are provision of alternate water supplies, active venting, or installation of treatment systems, primarily for aeration or degasification of the water supply. Details of gas well construction, and gas and water well remediation actions are given in Tables S1, S2, and S3 of the electronic supplementary material (ESM).

\section{Geochemical fingerprinting}

Analysis of stable carbon and deuterium isotopes of methane $\left(\mathrm{CH}_{4}\right)$ is the technique of "geochemical fingerprinting" used in petroleum exploration to identify methane sources (Schoell 1983). Methane originating from the burial of organic sedimentary matter at high temperatures and pressures is defined as thermogenic. Methane originating from bacterial fermentation or from the bacterially mediated reduction of carbon dioxide is defined as biogenic. The use of $\delta^{13} \mathrm{C}_{-} \mathrm{CH}_{4}\left(\delta^{13} \mathrm{C}_{1}\right)$ values in combination with $\delta^{2} \mathrm{H}-\mathrm{CH}_{4}\left(\delta \mathrm{DC}_{1}\right)$ values provides a method to distinguish different thermogenic and microbial gases. Equivalent ethane values are $\delta^{13} \mathrm{C}_{-} \mathrm{C}_{2} \mathrm{H}_{6}$ $\left(\delta^{13} \mathrm{C}_{2}\right)$ and $\delta^{2} \mathrm{H}-\mathrm{C}_{2} \mathrm{H}_{6}\left(\delta \mathrm{DC}_{2}\right)$. Isotope ratios are expressed as the difference in the molar ratio of the heavy to light isotope of a sample relative to the molar 
Fig. 2 Cross section $A-A^{\prime}$ of Upper and Middle Devonian formations near Dimock, Susquehanna County, Pennsylvania, USA

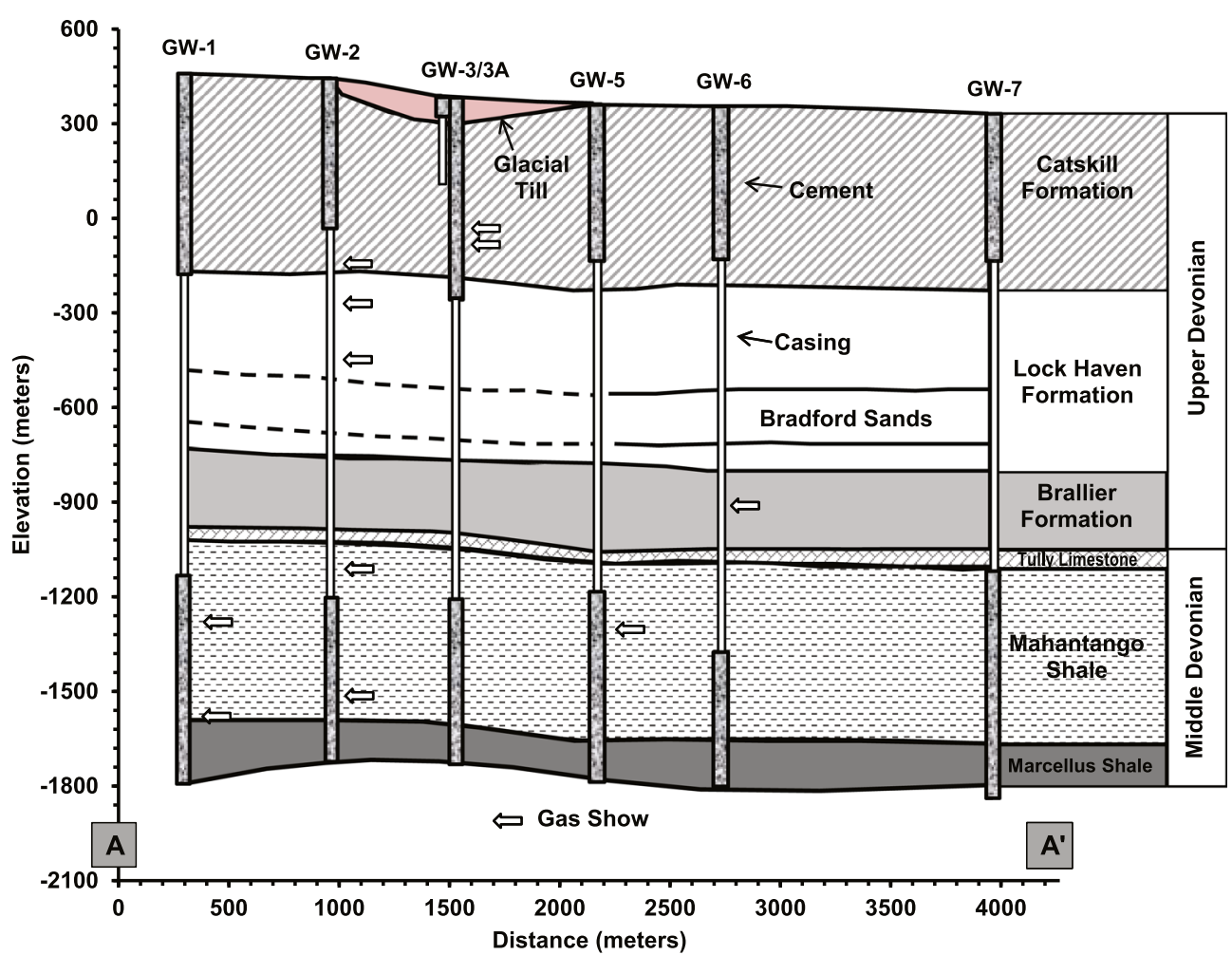

ratio of the heavy to light isotope of a standard, expressed in per mil or parts per thousand (\%o), using the following formula:

$\delta=\left[\left(R_{\text {sample }} / R_{\text {standard }}\right)-1\right] 1000$

where $\delta=$ isotopic ratio and $R=$ (rare/abundant) isotope

The standards are VPDB (Vienna Pee Dee Belemnite) for the carbon isotopes and VSMOW (Vienna Standard Mean Ocean Water) for the hydrogen isotopes. The differences between samples and standards are very small. More negative values of $\delta^{13} \mathrm{C}^{-} \mathrm{CH}_{4}$ and $\delta^{2} \mathrm{H}$ $\mathrm{CH}_{4}$ are said to be "depleted" in the heavier isotopes, while more positive values are said to be "enriched." The analytical techniques are described by Schoell (1980).

\section{Results}

Figure 3 is a flow diagram of the gas well operations at the eight gas well pads near Dimock to assist readers in following the discussion and reviewing the extensive amount of data and numerous changes related to methane migration that occurred due to gas well operations in the Dimock study area.

\section{Isotopic and molecular analysis}

Isotope analyses were reviewed for samples taken from gas and water wells in the subject area and are shown in a Schoell diagram (Fig. 4) and details are contained in Table S4 of the ESM. Initial samples were collected by PA DEP in 2009 from gas well annular spaces and water wells. Follow-on samples were analyzed by PA DEP and the operator in 2010, and the US EPA in 2012. In addition, analyses of samples taken from production casings and a gas pipeline were made by PA DEP and the operator. Several patterns in the data are apparent. The 2009 data for water wells and gas well annular spaces occur in one cluster, while there is a second cluster consisting of the data for the more enriched production gas samples. The low concentration $(<10 \mathrm{mg} / \mathrm{L}) 2012$ US EPA data are generally more enriched than the 2009 results, while the higher concentration samples are generally more depleted. The 2010 samples have relatively high concentrations and tend to be similar to or more depleted than the 2009 data.

For 17 of the 22 water well samples, the ratio of methane to ethane was less than 110, typical of thermogenic origin. One had a ratio of 277 and the remaining four samples had ratios between 2,789 and 6,667, which Molofsky et al. (2013) indicated were possibly from microbial gas sources, a mixture of different sources, and/or gases that have undergone alteration during migration. They further indicated that eight of the 11 water wells sampled by the US EPA in 2012 had combined $\delta^{2} \mathrm{H}$ and $\delta^{13} \mathrm{C}$ values of methane that were more depleted than 


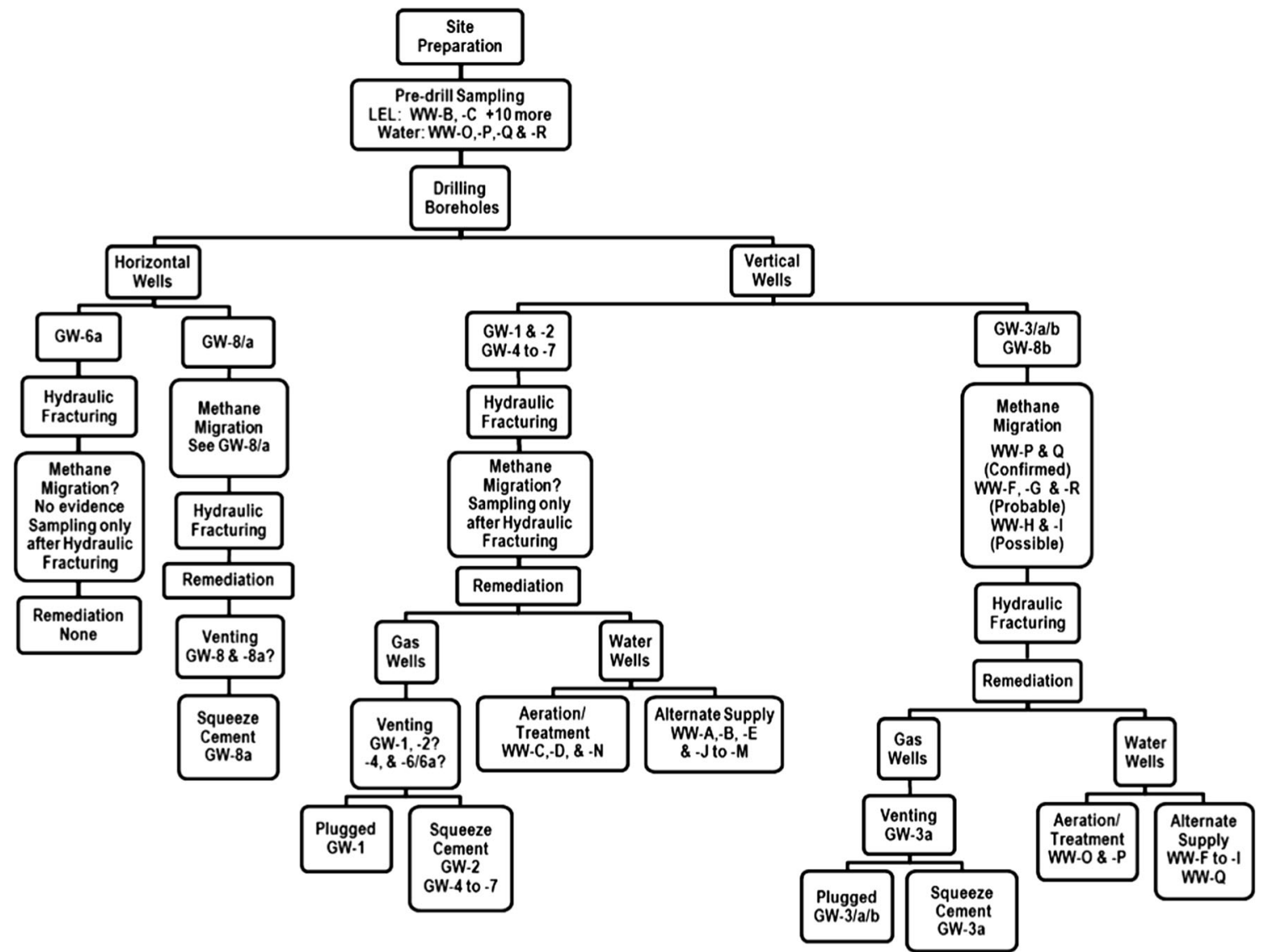

Fig. 3 Conceptual diagram of the relationship in the study area between gas well operations and methane migration

Fig. 4 Schoell diagram of methane gas samples in the study area analyzed by the PA DEP, the US EPA and the operator. Adapted from Schoell (1983). B bacterial gas; $M$ mixed gas; $T O$ oil associated thermogenic wet gas; $T C$ condensate associated thermogenic wet gas; and $T D$ dry thermogenic dry gas

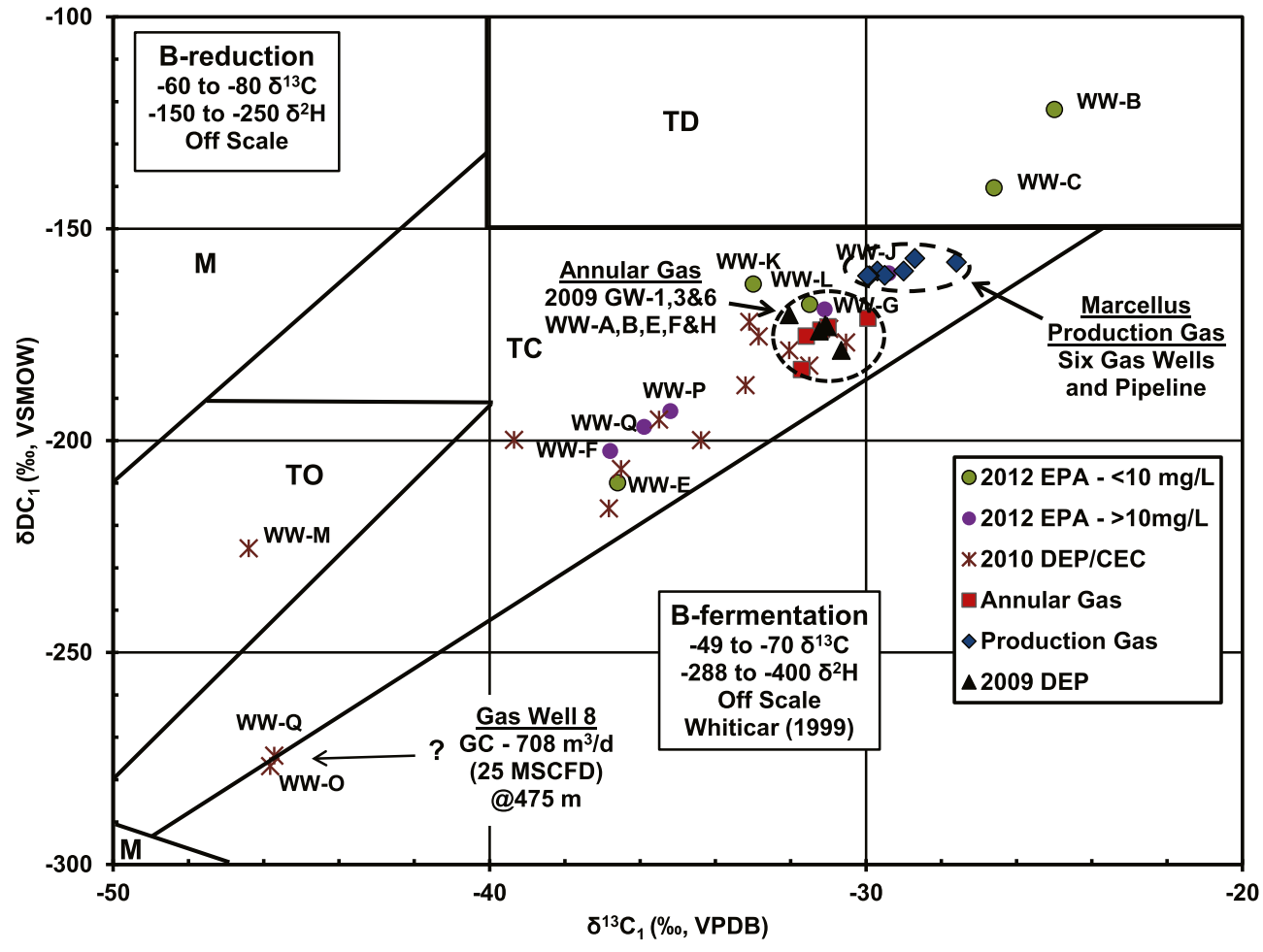


production gases. The signatures of the remaining three samples (WW-B, -C and -J) appeared to match Marcellus production gas; however, they indicated that microbial oxidation in the subsurface was likely responsible for the elevated $\delta^{2} \mathrm{H}$ and $\delta^{13} \mathrm{C}$ values. Various samples were analyzed for propane, but no obvious trends could be found in the present study, except that samples with clearly thermogenic signatures tended to contain propane and the others did not.

Molofsky et al. (2013) did not consider the effects of gas shale operations on the temporal variation of methane and ethane isotopes in the water wells. Figure 5 and Table S5 of the ESM include methane and ethane data collected prior to and after gas well remedial actions. Five water wells (WW-A, WW-B, WW-E, WW-F, and WW-H) were sampled in 2009 prior to any remediation and had $\mathrm{C} 1: \mathrm{C} 2$ ratios of about 50 . All but WW-A were sampled after remediation. After remediation, the ratios of WW-E and WW-H were relatively unchanged, while the ratios for WW-B and WW-F nearly doubled, although WW-B was enriched and WW-F was depleted relative to their earlier samples. Both WW-J and WW-K were first sampled in 2010 prior to remediation of GW-5 and after remediation of GW-6, respectively, with the ratio of the later samples increasing by $66 \%$ in WW-J, but only $15 \%$ in WW-K. The samples for the remaining wells (WW-G, WW-I and WW-L) were all collected after remediation and the $\mathrm{C} 1: \mathrm{C} 2$ ratios increased by $16-25 \%$.

The data indicate that the methane was significantly enriched in 2012 in wells WW-B and, probably, WW-C, relative to the 2009 data, likely due to microbial oxidation. The methane in 2012 in wells WW-E and WW-F was significantly depleted relative to the 2009 data, probably due to methanogenesis under anaerobic conditions. There were lesser changes in the isotope signatures for WW-G, -J and -L. The significance of the relationship between changes in the isotopic signatures and gas ratios relative to gas well operations and the effectiveness of remediation action are discussed later.

Kotelnikova (2002) found evidence of active methanogenesis and presence of viable methanogens for some subsurface environments including water-flooded oil fields, deep sandy aquifers, deep-sea hydrothermal vents, deep sediments and granitic groundwater at depths of $10-2,000 \mathrm{~m}$ below sea level. Baldassare et al. (2014) collected samples for molecular and isotopic analysis during mud gas logging (MGL) programs of 234 wells in northeastern Pennsylvania, including Susquehanna County. Tables S6 and S7 of the ESM classify the isotopes of those samples by formation of origin and sample depth. Added to the tables are the samples in the present study, classified by formation and depth. Due to the substantial overlap in the MGL categories, the ages and depths of the Dimock samples are only approximate.

These results indicate that the source of methane for the samples collected in 2009 was the Tully Limestone, with one sample from the immediately overlying Geneseo Shale (not mapped in the Dimock study area), at depths of 1,219-1, $524 \mathrm{~m}(4,000-5,000 \mathrm{ft})$. All had $\mathrm{C} 1: \mathrm{C} 2$ ratios less than 110, indicating a thermogenic origin. In 2010, the samples are relatively evenly distributed between the Tully Limestone and the three younger formations. Nine were at depths of about
Fig. 5 Methane and ethane concentrations (mole \%) from samples collected in water wells before and after gas well remediation actions

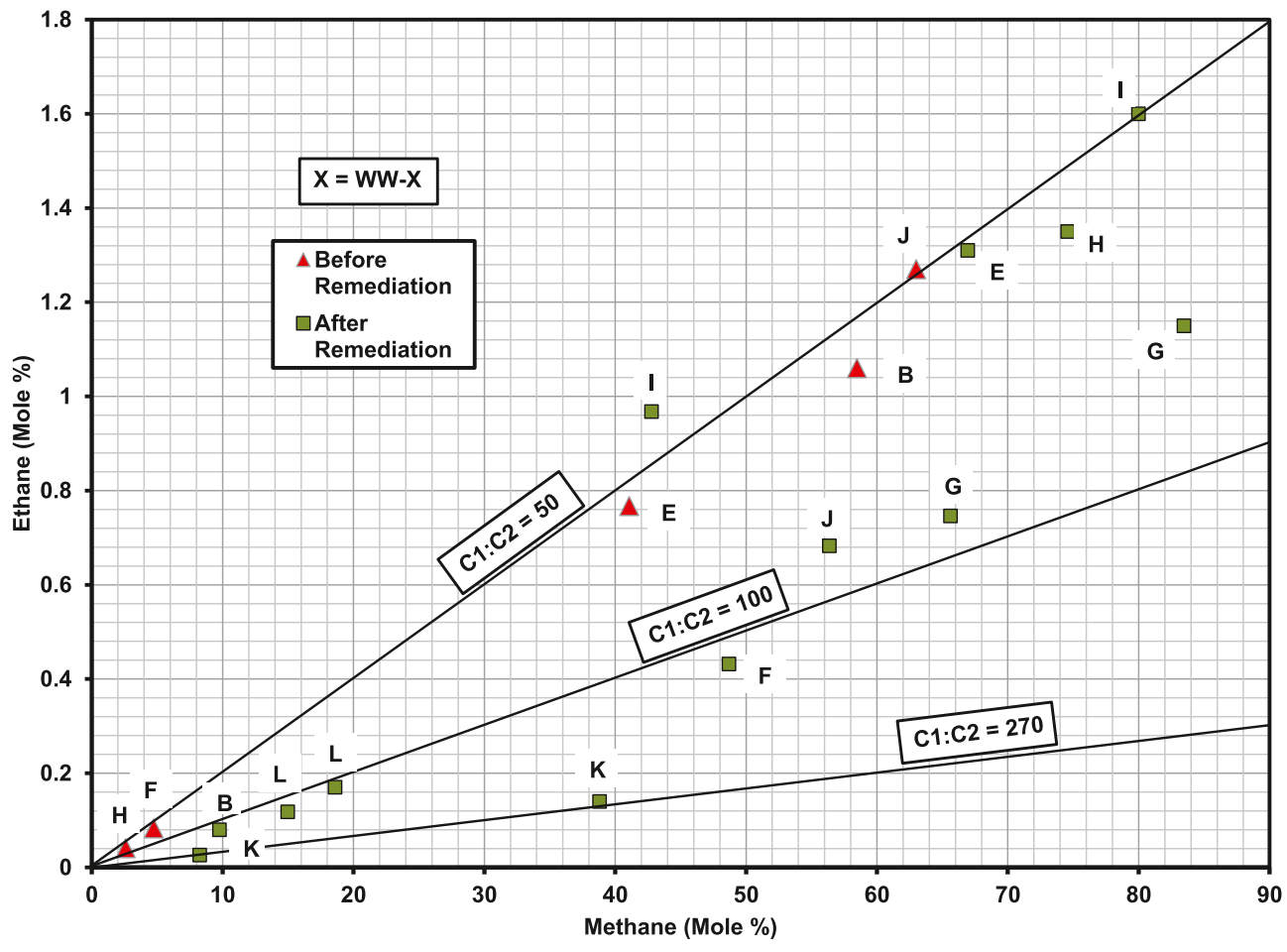


914-1,524 m (3,000-5,000 ft), two of which had been sampled in 2009 (WW-E and WW-H) and were substantially altered. Two (WW-P and WW-R) had C1:C2 ratios $>2,500$, suggesting a microbial origin at a depth greater than $610 \mathrm{~m}$ $(2,000 \mathrm{ft})$. Three were possibly sampled between 0 and $305 \mathrm{~m}$ $(1,000 \mathrm{ft})$, only one $(\mathrm{WW}-\mathrm{M})$ of which had a $\mathrm{C} 1: \mathrm{C} 2$ ratio $>2$, 500 , suggesting a microbial gas, while the other two had thermogenic signatures. By 2012, in at least eight, and possibly nine, of the 10 wells sampled, the methane compositions had been altered after remediation, most likely by microbial oxidation or methanogenesis. The methane in the last one (WW-P) appears to have a natural origin, unaffected by gas shale well operations.

\section{Well site investigations}

The results of the field investigations at three sites ( $\mathrm{GW}-1$, GW-3/a/b and GW-4, and GW-8/a/b) are presented in the following text. These were the ones with the greatest number and degree of impacts, and provide the best examples of the effects of gas well operations on methane migration. The results from the remaining sites $(\mathrm{GW}-2$, GW-4, GW-5 and GW-6, GW6/a, and GW-7) are discussed in the ESM.

\section{Gas well $1(G W-1)$ and water wells $A$ to $D(W W-A$ to $-D)$}

Before construction of GW-1, LEL measurements were taken in four house wells, including WW-B and WW-C, Table S8 of the ESM, within $457 \mathrm{~m}$ of that gas well, with no detection of methane. Post-drilling/fracturing LEL measurements for WW-B and -C were less than $1 \%$, respectively; however, this occurred shortly before squeeze cementing of GW-1 and may have been related to venting of that gas well. On 1/1/2009 an explosion blew the pit cover off WW-A. Of the 12 nearby water wells sampled starting on $1 / 5 / 2009$, methane was not detected in seven and two had levels less than $1 \mathrm{mg} / \mathrm{L}$. The remaining three wells, WW-A, -B and -C, had methane concentrations of $4.0,8.0$ and $17.6 \mathrm{mg} / \mathrm{L}$, respectively. Isotopic analyses of WW-A and -B were very similar to the two measurements taken between the annular space of GW-1, but different than the production gases and gas taken from the associated pipeline.

While venting GW-1 during the period 1/20-27/2009, PA DEP LEL readings in WW-A and -C declined from 60 and $40 \%$ to 2 and $0 \%$, respectively, while the levels in WW-B dropped from 55 to $22 \%$. There were some significant differences between the operator and PA DEP readings on certain common dates, so the LEL measurements were only used for screening purposes in the present study. Figure 6 is a graph of methane chemistry and related operational records for WW-A and -D. Prior to late 2009 the methane levels in WW-A average $6.8 \mathrm{mg} / \mathrm{L}$, then after late 2010 they average $0.6 \mathrm{mg} / \mathrm{L}$. The homeowner was provided with an alternate water supply starting 10/22/2009, so the lower methane concentrations during the later period could be due to reduced water use from the well, but could also be related to remediation by squeezing and plugging of the gas well. In early 2009 , the maximum concentration in WW-D was $0.1 \mathrm{mg} / \mathrm{L}$. In April 2010, after an approximate 1-year data gap, the methane level in the well was $39 \mathrm{mg} / \mathrm{L}$. After GW-1 was plugged, methane in WW-D steadily declined to zero after about $21 / 2$ months. Four months later, the concentration was $31.8 \mathrm{mg} / \mathrm{L}$ and fluctuated between that level and $0 \mathrm{mg} / \mathrm{L}$ until the end of the record. Since this was not the homeowners' primary residence, the final low methane levels may have been due to limited use from the water well and/or remediation of the gas well.

The methane and operational data for WW-B and $-\mathrm{C}$ are shown in Fig. 7. The low concentration on 5/23/2009 in WW$\mathrm{B}$ may have been the result of venting of GW-1. There are three high concentrations in the late-time data for WW-B, while most of remaining ones are at or near $0 \mathrm{mg} / \mathrm{L}$. The homeowner was provided with bulk and bottled water starting on $7 / 20 / 2009$. The later, low methane concentrations may have been due to limited use from the water well and/or remediation of the gas well. While the initial isotope signature for WW-B was similar to that of the annulus sample from GW-1, the final sample from the water well was substantially more enriched in heavy isotopes, probably by microbial oxidation. This indicates that there may have been two sources present. Probably, at early time, leakage from the annulus dominated the mixture, while the later enriched sample at the much lower concentration represented naturally occurring methane.

The 2009 methane concentrations in WW-C are initially relatively high, declining until the middle of the year and then increasing until the end of the year, with the late-time values showing much greater variation. An aeration treatment system was installed on the well system during May 2010, at the same time that GW-1 was plugged. At least two samples with low concentrations of methane were taken before treatment was added. When in operation, a relatively inefficient or low yielding well can produce substantial water level fluctuations that could have produced the rapid changes in methane concentrations noted in WW-C. GW-1 was plugged between the two periods of record, which could account for the overall change in the pattern of methane levels. Isotopic analyses of a sample from WW-C were substantially more enriched than that of the GW-1 annular gas, but an early isotopic analysis was needed to determine if two sources were present.

Gas wells $3 / 3 a / 3 b$ and $4(G W-3 /-3 a /-3 b$ and -4$)$ and water wells $F$ to $I$ (WW-F to $-I)$

GW-3 was drilled to a depth of $271 \mathrm{~m}$, with glacial till from the surface to $73 \mathrm{~m}$. A conductor casing was set at $58 \mathrm{~m}$ and grouted, leaving $15 \mathrm{~m}$ of till open to the annular space. GW-3b 
Fig. 6 Methane concentrations and stable isotope compositions of samples from $W W-A$ and $-D$, near $G W-1$. Included are gas well operations and other activities possibly related to methane gas migration

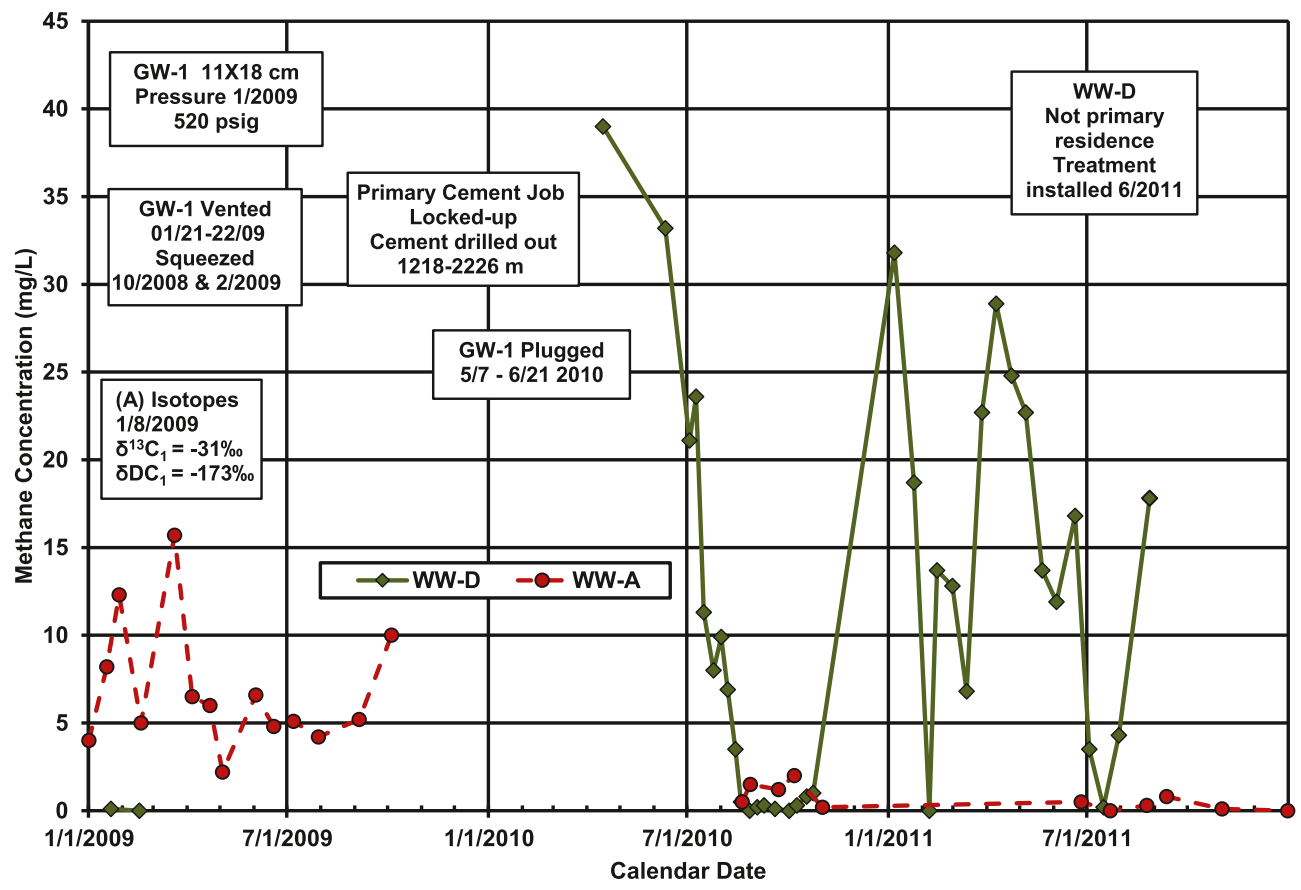

was completed to a depth of $582 \mathrm{~m}$. Both were conventional wells and neither was hydraulically fractured. GW-3 was plugged from 0 to $110 \mathrm{~m}$, because the drill string was stuck in the well bore, but had to be drilled out and re-plugged to the total depth in January 2009. GW-3a was drilled about $9 \mathrm{~m}$ from GW-3 to a vertical depth of $2,124 \mathrm{~m}$, and was then plugged on $5 / 23 / 2010$, along with GW-3b. It is further noted that GW-3a was not hydraulically fractured until 3/20/2009, several months after high methane levels were observed in nearby water wells. A pressure of 282 psig was measured in the annulus of GW-3a on $1 / 26 / 2009$, requiring a squeeze cement job to be performed on that well on 4/3-5/2009. GW-4 was completed on $10 / 14 / 2008$ to a depth of $2,148 \mathrm{~m}$ and stimulated on $9 / 30 / 2008$ and $10 / 1 / 2008$, prior to the initial water samples taken in nearby house wells. An annulus pressure of 345 psig was measured in that well on $1 / 21 / 2009$; but

Fig. 7 Methane concentrations and stable isotope compositions of samples from $W W-B$ and $-C$, near $G W-1$. Included are gas well operations and other activities possibly related to methane gas migration

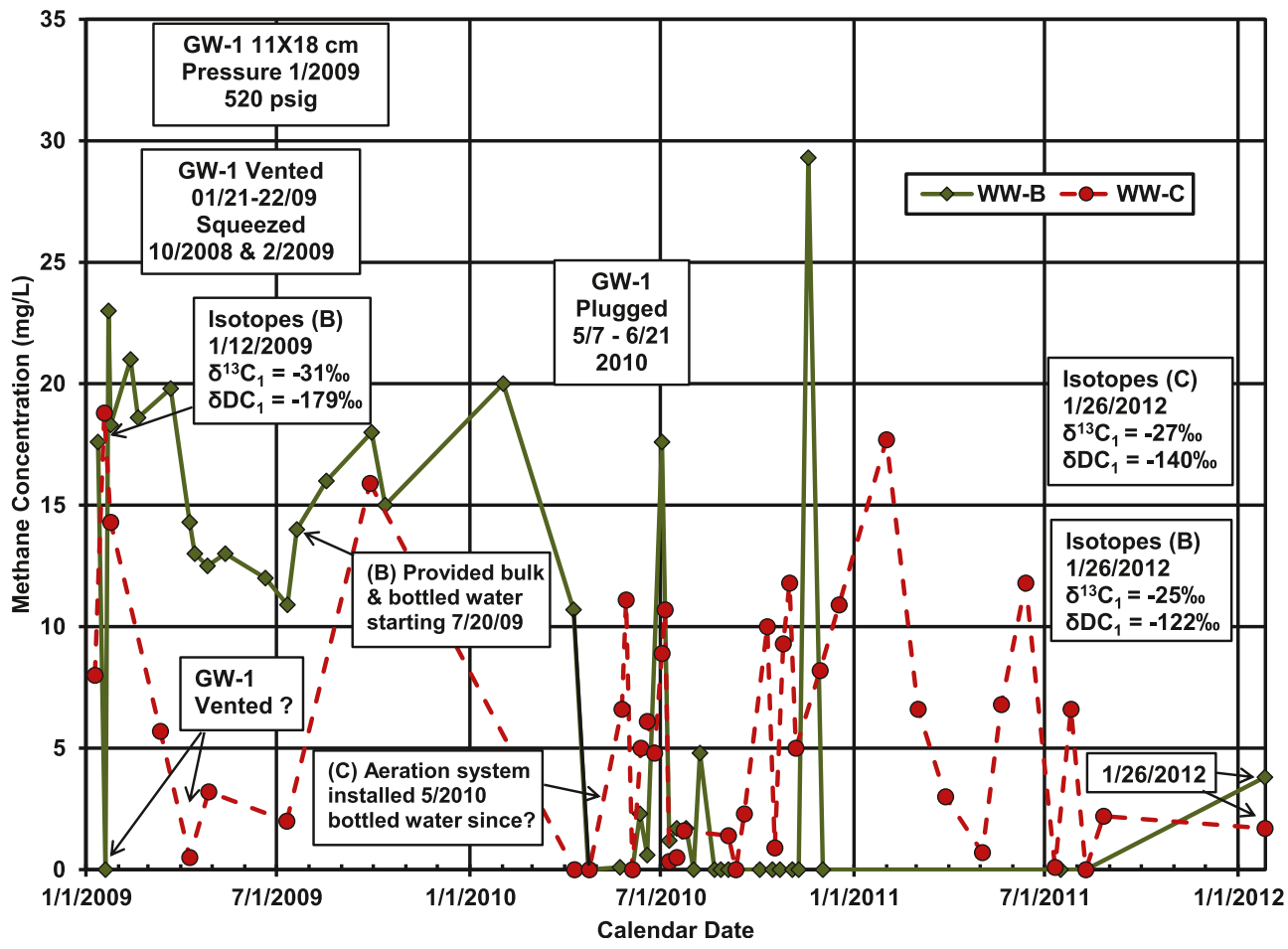


there were no reported annular space leaks. A squeeze job was performed on GW-4 on 3/18/2009.

Prior to construction of GW-3/-3a/-3b and -4, LEL measurements were taken in three house wells within $457 \mathrm{~m}$ of the gas wells, with no detection of methane. On 1/14/2009 and $1 / 18 / 2009$, high methane levels were measured in WW-F and WW-H, -G and -I, respectively. PA DEP reported gas leaking from the GW-3a $51-\mathrm{cm}$ casing and between the 51 and $34-\mathrm{cm}$ casings, and that venting of the annulus of that well, as well as GW-4, was started $1 / 22 / 2009$. On $1 / 27 / 2009$, the methane concentration had declined to 5.6 and $2.14 \mathrm{mg} / \mathrm{L}$ in WW-H and -I, respectively, probably as a result of the venting. On the same date, the methane concentration in WW-G was $20.9 \mathrm{mg} /$ $\mathrm{L}$, but it was declining. No samples were taken from WW-F during the period when the gas wells were being vented. Between $1 / 23 / 2009$ and $1 / 27 / 2009$, the LEL levels remain relatively unchanged in WW-F and - $\mathrm{H}$, but then appear to increase to the end of the record on 2/4/2009. The LEL levels in WW$G$ and -I are zero throughout the entire record. In both of those cases, the operator indicated that the cause was probably related to the effects of separator type devices installed on each well.

Long-term records of methane chemistry for WW-F, $-\mathrm{G},-\mathrm{H}$ and -I wells, with related shale gas well operations are shown in Figs. 8 and 9. Prior to squeezing and/or plugging of GW-3a/ $-3 b$ and -4 , methane concentrations in WW-G varied from 19 to $44 \mathrm{mg} / \mathrm{L}$, with an average of $26.9 \mathrm{mg} / \mathrm{L}$. Immediately after plugging of $\mathrm{GW}-3 \mathrm{a} /-3 \mathrm{~b}$, the methane level declined to $0.02 \mathrm{mg} / \mathrm{L}$, probably due to venting of the gas wells; however, there is no record of venting on that date. After plugging of
GW-3a/-3b, the average concentration in WW-G was $33.9 \mathrm{mg} / \mathrm{L}$, indicating that there were no apparent changes in the methane concentrations in that well, after remediation of the gas wells. The periodic fluctuations in the methane concentrations could be due to natural variation; however, based on the Molofsky et al. $(2011,2013)$ regional background data, where only 2 of 1,379 "pre-drill" samples exceeded methane levels of $28 \mathrm{mg} / \mathrm{L}$, the overall average of $30.3 \mathrm{mg} / \mathrm{L}$ and maximum of $64 \mathrm{mg} / \mathrm{L}$ in WW-G would be expected to occur less than $0.2 \%$ of the time. Two methane samples taken in WW-F prior to plugging of the gas wells were 24.7 and $42.7 \mathrm{mg} / \mathrm{L}$. Six measurements were taken after plugging, ranging from 2.5 to $18.3 \mathrm{mg} / \mathrm{L}$, with an average of $11.3 \mathrm{mg} / \mathrm{L}$.

Prior to remediation, methane levels in WW-H and -I were $30-48 \mathrm{mg} / \mathrm{L}$ (neglecting samples possibly collected during gas well venting). After squeezing of GW-3a/-3b and -4 , there is a decline in the methane concentrations in well WW-I; however, the three lowest values (on 8/13/09) appear to have been taken after or downstream of the water well treatment system. After that time, there is a substantial increase in the methane levels, indicating that remediation was only initially successful. After plugging of GW-3a/-3b, the values for WW-H and -I varied from 29 to $61 \mathrm{mg} / \mathrm{L}$.

Isotopic analyses of the samples from WW-F and -H taken on $1 / 21 / 2009$ produced values similar to the two measurements taken from the annular spaces of GW-3a. After remediation, isotopic analyses of water from WW-G, -H and -I have signatures slightly more depleted than that of gas leaking from the annular spaces of GW-3a. The follow-on US EPA sample of WW-G is slightly more enriched than the annular
Fig. 8 Methane concentrations and stable isotope compositions of samples from $W W-F$ and $-G$, near $G W-3,-3 a$ and $-3 b$. Included are gas well operations and other activities possibly related to methane gas migration

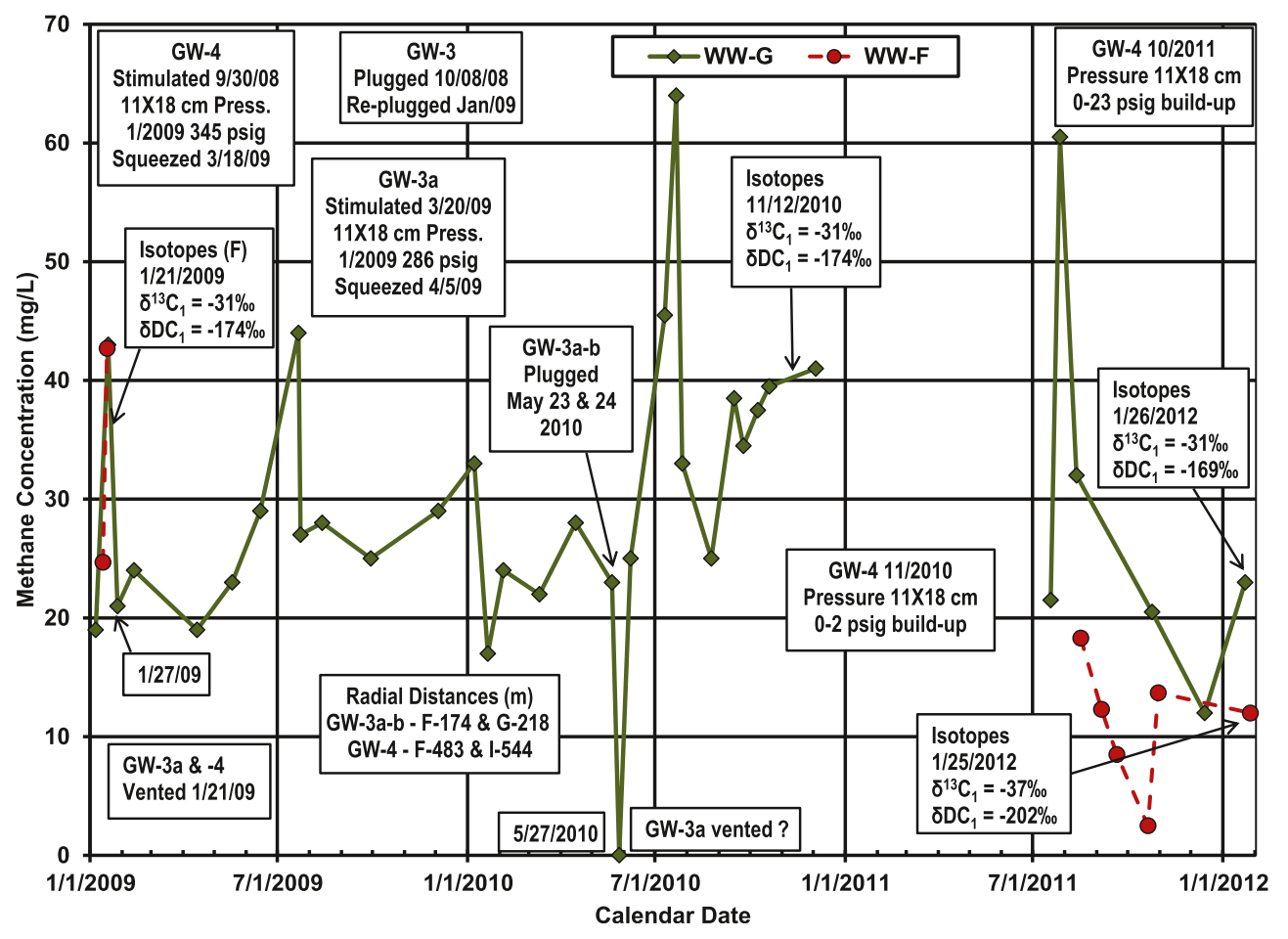


Fig. 9 Methane concentrations and stable isotope compositions of samples from $W W-H$ and $-I$, near $G W-3,-3 a$ and $-3 b$. Included are gas well operations and other activities possibly related to methane gas migration

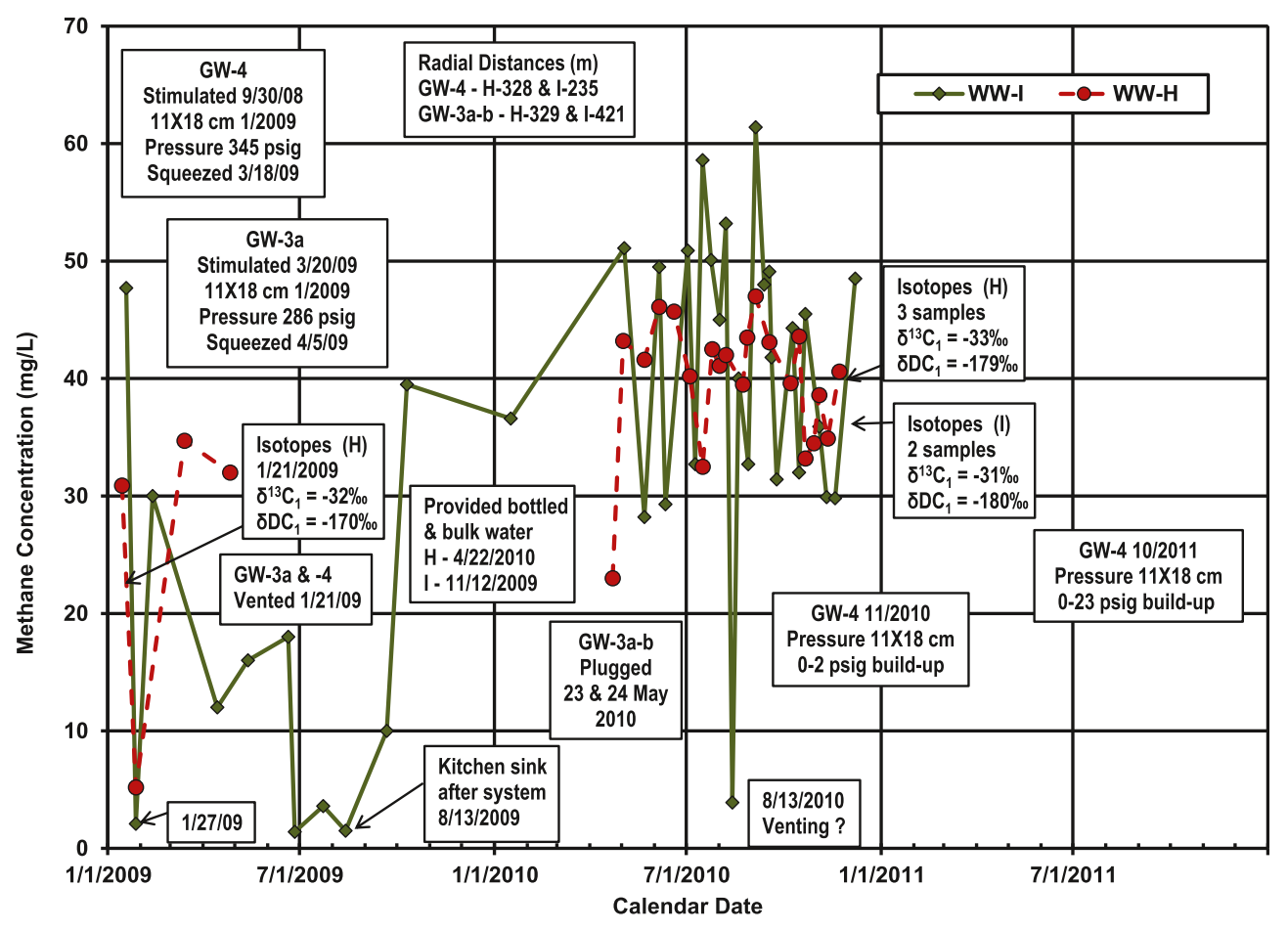

space gas. After remediation and plugging of the gas wells, the US EPA sample collected from WW-F was substantially more depleted than the annular space gas, suggesting a less mature methane source. These data indicate that remediation of GW$3 /-3 a /-3 b$ and -4 may have mitigated some of the impacts to WW-F, but had little or no effect on WW-G, -H and -I. It is noted that a portion of the annular space of GW-3 was not cemented and, possibly, remained open to glacial till sediments after plugging of the well, providing a potential continuing pathway for methane migration.

\section{Gas wells 8/8a/8b (GW-8/-8a/-8b) and water wells $O$ to $R$ $(W W-O$ to $-R)$}

This is the one gas-well-pad site where some predrilling water samples were taken from nearby house wells. Long-term records of methane chemistry and related gas well operations for WW-O, -P, -Q and -R are shown in Figs. 10 and 11. GW-8 was completed in two phases, one ending 11/23/2008 and the other on $4 / 8 / 2009$. On $1 / 21 / 2009$, the well's annulus pressure was 340 psi and it was initially vented on $1 / 22 / 2009$, with no apparent effect on any of the water wells. GW-8b was completed 5/15/2009, also with no apparent effect on methane levels. Prior to the completion of GW-8a on $7 / 13 / 2009$, the methane concentrations varied from 0.8 to $23 \mathrm{mg} / \mathrm{L}$ and were relatively steady in the individual water wells. These were levels consistent with the Molofsky et al. (2013) and operator's pre-drilling concentrations in the Meshoppen Creek watershed. After completion of GW-8a, there are substantial increases in the concentrations in all water wells, but at different rates. The most rapid increase occurs in the WW-Q; there was a delay in response of at least 7 days in WW-O; and methane concentrations in WW-P changed at a slow rate. There is a large gap in the data for WW-R, with the methane levels increasing from an initial $0.8 \mathrm{mg} / \mathrm{L}$ to an average of $51 \mathrm{mg} / \mathrm{L}$ during later periods. The later concentrations in the water wells are much greater than the predrilling samples contained in the Molofsky et al. (2013) study and operator records, indicating that they were not a natural occurrence.

The methane levels in WW-Q remain elevated until 10/29/ 2009, at which point they drop to near $0 \mathrm{mg} / \mathrm{L}$ for about 6 months, when the homeowner was provided with bottled and bulk water. The response indicates that the water well was probably not used during that period. On 9/12/2010, the concentration increases to $25.2 \mathrm{mg} / \mathrm{L}$ and remains elevated for the remainder of the record, except for one measurement. After the GW-8a annular space was squeezed, there was no significant change in the methane level in WW-Q until 10/28/ 2010, when it declined to $0.5 \mathrm{mg} / \mathrm{L}$, possibly due to either venting of the GW-8a, the water well was not in use, or a combination of both factors. On 11/3/2010, the methane concentration then increases to $30.9 \mathrm{mg} / \mathrm{L}$ and remains elevated for the remainder of the record. The 2012 US EPA $52 \mathrm{mg} / \mathrm{L}$ sample may have been taken from either WW-Q or -R. The uncertainty in the well identification is because the US EPA samples do not include locational data. The well number assigned by the US EPA (HW-12) is the same as that used by Molofsky et al. (2011) and corresponds to WW-Q. The isotopic signature and concentration, however, are similar to earlier samples from WW-R and substantially different than 
Fig. 10 Methane concentrations and stable isotope compositions of samples from $W W-O$ and $-P$, near $G W-8,-8 a$ and $-8 b$. Included are gas well operations and other activities possibly related to methane gas migration

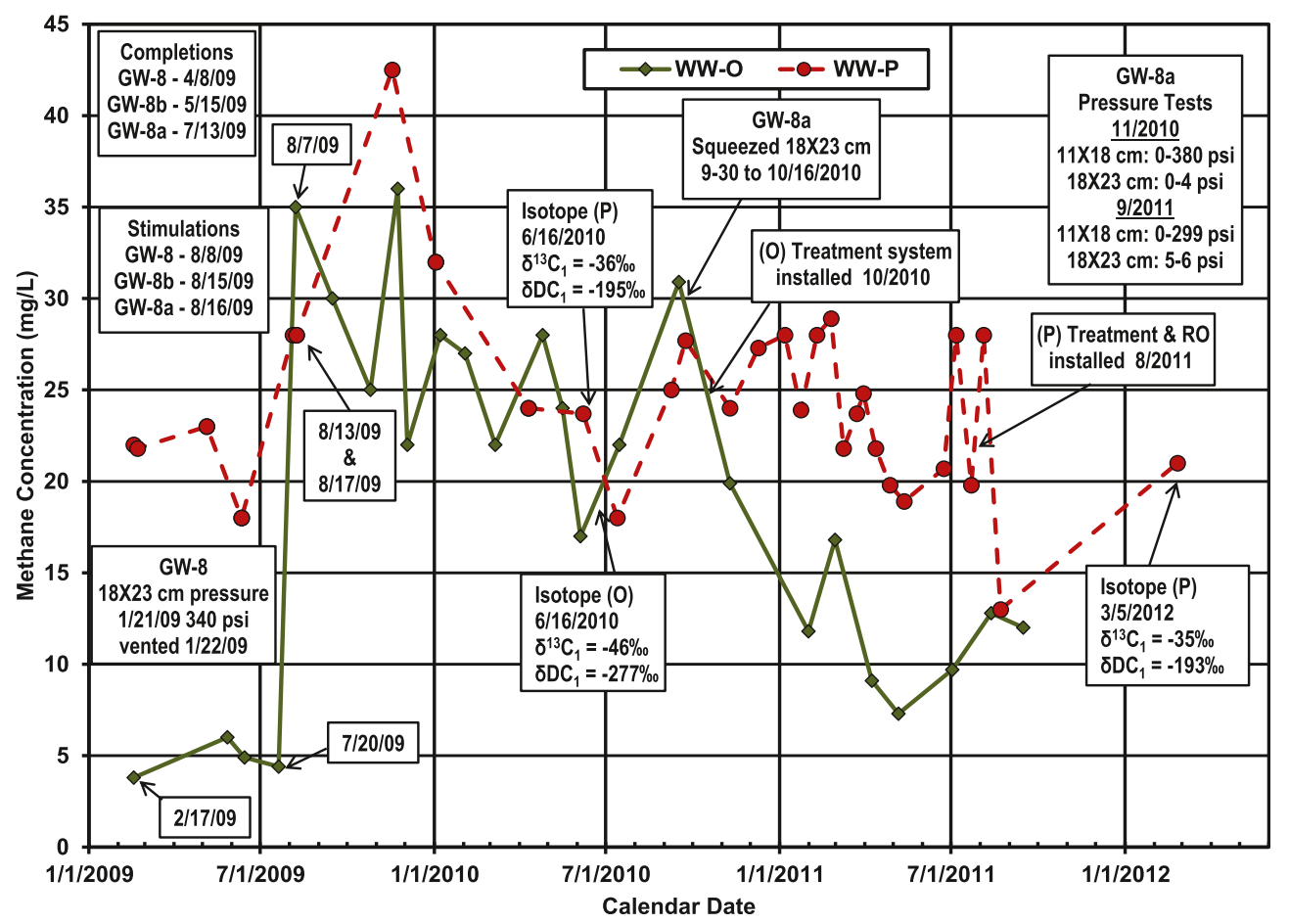

those taken from WW-Q, but the $\mathrm{C} 1: \mathrm{C} 2$ ratio is similar to that for WW-Q. Finally, only WW-Q is included on any of the lists of impacted water supplies. The best estimate is that the sample was taken from WW-Q.

The methane concentrations in the WW-O remain elevated until 9/16/2010, at which point they decrease to about $10 \mathrm{mg} /$ $\mathrm{L}$ near the end of the record, a decline which occurred immediately after the GW-8a annulus was squeezed. In the case of WW-P, methane levels increase from $18 \mathrm{mg} / \mathrm{L}$ on $6 / 20 / 2009$ to $28 \mathrm{mg} / \mathrm{L}$ on $8 / 13 / 2009$, prior to stimulation of GW-8a and GW-8b, but after GW-8 was stimulated. After reaching a peak of $42.5 \mathrm{mg} / \mathrm{L}$, the concentration decreases to near pre-drilling levels on or before $4 / 19 / 2010$, a decline that occurs more than 5 months before the squeezing of GW-8a
Fig. 11 Methane concentrations and stable isotope compositions of samples from $W W-Q$ and $-R$, near $G W-8,-8 a$ and $-8 b$. Included are gas well operations and other activities possibly related to methane gas migration

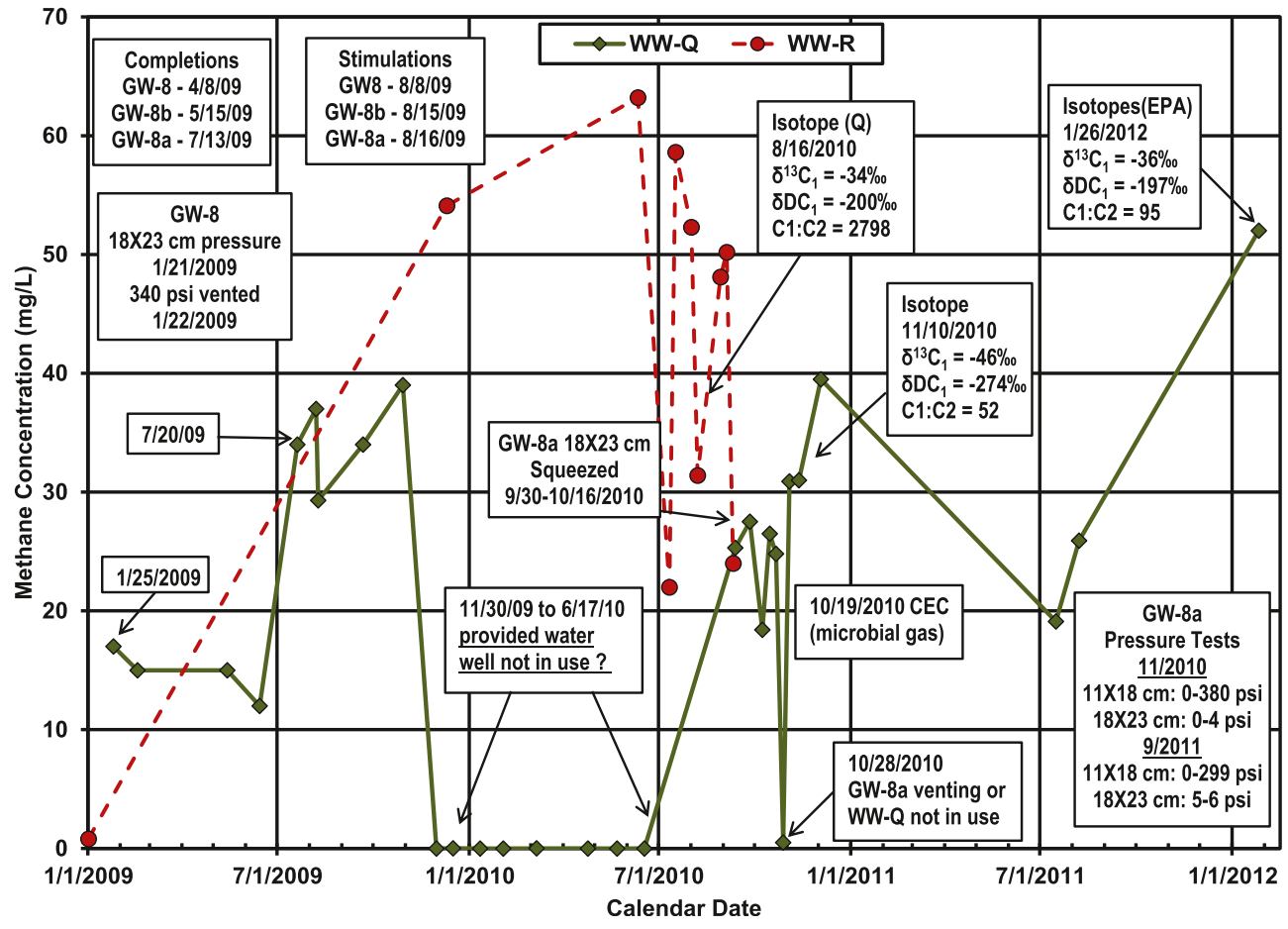


and remains near those levels until the end of the record, indicating that methane had not migrated to WW-P.

It is important to note that the increased methane concentrations in WW-O and WW-Q occurred before the three gas wells were stimulated between $8 / 8$ and $8 / 162009$. There is a gap in the data for WW-R during the period when the gas wells were drilled and stimulated.

The results of isotopic analyses and $\mathrm{C} 1: \mathrm{C} 2$ ratios of the samples taken from WW-O and -Q indicate that the gases were immature thermogenic methane relative to the samples collected along Carter Road, suggesting a source from younger and shallower formations. This is supported by a gas flow of $708 \mathrm{~m}^{3} /$ day reported from GW-8 at $475 \mathrm{~m}$. There is no shallow mud log available for well GW-8a, the most probable conduit for the migrated methane. For WW-P and -R, the isotopic analyses indicate a more mature thermogenic origin for the methane, but the $\mathrm{C} 1: \mathrm{C} 2$ ratios indicate there is a biogenic component, possibly due to microbial alteration. A follow-on US EPA sample was collected from one of the water wells in 2012, which could have been taken from either WW-Q or WW-R, but most likely from WW-Q. If the followon 2012 US EPA sample were from WW-Q, then the sample was more enriched than the earlier sample, indicating that a source of methane had migrated.

The methane chemical and operational data indicate that remediation of GW-8a mitigated the impacts to WW-O. Squeezing of the gas well may have had little or no effect on either WW-Q or -R; since the methane levels remained unchanged or increased after remediation. No evidence could be found that methane migration impacted WW-P.

\section{Discussion}

PA DEP found no measurable LEL levels of methane in 12 water wells sampled prior to drilling in the area of Carter Road. After drilling, six of seven wells (WW-A, -B, -C, -E, $\mathrm{F}$ and $-\mathrm{H}$ ) sampled had maximum combustible levels between 5 and $60 \%$. The remaining one (WW-G) had a level of $0 \%$, but it was equipped with a separator type device.

Prior to remediation of any gas wells; of the 39 water wells within $785 \mathrm{~m}$ of an active gas well (GW-1 through GW-6/6a) in the Burdick Creek basin, $12(31 \%)$ had maximum methane levels $\geq 10 \mathrm{mg} / \mathrm{L}$, including $6(15 \%)$ with maximum levels $\geq$ $28 \mathrm{mg} / \mathrm{L}$. The proportions of water wells equal or exceeding the two hazard limits were considerably higher than the values for "predrilling sites" contained in regional studies $(3 \% \geq$ $10 \mathrm{mg} / \mathrm{L}$ and $0.2 \% \geq 28 \mathrm{mg} / \mathrm{L}$ ).

Along Carter Road, isotopic data collected prior to remediation in six water wells matched the signatures of those taken from the annular spaces of three gas wells, but not the signatures of Marcellus production gases. After remediation, the methane from two of those water wells was more enriched than before, while two wells had more depleted samples and the remaining two were not sampled. In the first case, one well (WW-B) was located in an upland area, underlain by bedrock or a very thin layer of glacial till, where aerobic microbial oxidation would be expected. The second well (WW-J) was located in a valley, where anaerobic conditions would be expected; except, if aerobic zones of a wetland were present. Of the two depleted samples, one (WW-F) was located in a valley, where anaerobic conditions might exist. The second (WW-E) was found at or near an upland elevation, but oxidation potential at that site might have been reduced by cultivation practices

Six other water wells along or near Carter Road were sampled after remediation. Three (WW-G, -H and -I) had high concentrations and isotope compositions that matched annular space methane signatures, suggesting that mitigation of the impacts to those water wells was ineffective. One sample from WW-L matched annular gas signatures, but had low concentrations $(2-5 \mathrm{mg} / \mathrm{L})$ after remediation. This would indicate that the impacts were effectively mitigated, although some migrated methane was still present. One sample from WW-C was enriched relative to annular gases, probably due to microbial oxidation, had a lower concentration and was in an upland area, suggesting a natural occurrence and that two sources might have been present prior to remediation. The sample from the final well (WW-K) was enriched relative to the earlier sample collected between squeeze cementing of GW-5 and GW-6. In that case, there may have been two sources present prior to remediation.

Six of 24 water wells $(25 \%)$, within about $785 \mathrm{~m}$ of the two (GW-7 and GW-8,-8a and -8b) gas well pads located in the Meshoppen Creek watershed, had methane concentrations $\geq$ $10 \mathrm{mg} / \mathrm{L}$, including five ( $21 \%$ ) with levels $\geq 28 \mathrm{mg} / \mathrm{L}$. Based on the findings of Molofsky et al. $(2011,2013)$ and the operator's data, it is estimated that about one third of 22 predrilling samples within the Meshoppen Creek basin were $\geq 10 \mathrm{mg} / \mathrm{L}$, but only one sample was $\geq 25 \mathrm{mg} / \mathrm{L}$ ( $<5 \%$ occurrence). These data indicate that the methane levels in the water wells near GW-7, GW-8, $-8 \mathrm{a}$ and $-8 \mathrm{~b}$ were much greater than the "predrilling" samples in the regional studies.

At the last site $(\mathrm{GW}-8 / \mathrm{a} / \mathrm{b})$, the concentrations of methane in four wells (WW-O to -R) of the 10 within $785 \mathrm{~m}$ of the gas wells increased from maximums of $0-23 \mathrm{mg} / \mathrm{L}$ prior to drilling to $36-63 \mathrm{mg} / \mathrm{L}(40 \% \geq 28 \mathrm{mg} / \mathrm{L})$ after drilling of the last gas well (8a) was completed. Most importantly, the increases occurred prior to any hydraulic fracturing in two wells (WW$\mathrm{O}$ and $-\mathrm{Q}$ ) and, possibly, a third one (WW-R). There were no known samples taken from the annular spaces of any of the gas wells at that site. The $17.8 \times 22.9 \mathrm{~cm}$ annular space in $\mathrm{GW}$ $8 \mathrm{a}$ was squeezed; however, the pressures in $10.2 \times 17.8 \mathrm{~cm}$ annular space of that well increased from 0 to 299 and 380 psi during two post-remediation shut-in pressure tests. The concentrations in one water well (WW-P) appear to have 
been from a natural source, since the methane levels in that well declined to near pre-drilling levels prior to any remediation efforts. In that case, the isotopes indicated a relatively mature thermogenic origin. The methane levels in another well (WW-R) increased from $0.8 \mathrm{mg} / \mathrm{L}$ prior to drilling to an average of $51 \mathrm{mg} / \mathrm{L}$ and a maximum of $63 \mathrm{mg} / \mathrm{L}$ after gas well construction. An isotope analysis indicated that the gas in that well was from a relatively mature thermogenic source; but, again the $\mathrm{C} 1: \mathrm{C} 2$ ratio $(>2,700)$ suggests a microbial component was present. The water well (WW-O) with the greatest increase immediately after drilling $(5-35 \mathrm{mg} / \mathrm{L})$ also had the greatest decrease after remediation (20-30 to $10-15 \mathrm{mg} / \mathrm{L}$ ); however, aeration treatment was installed in the well system at about the same time as the gas well $(\mathrm{GW}-8 \mathrm{a})$ was squeezed. The isotope compositions and $\mathrm{C} 1: \mathrm{C} 2$ ratio (109) indicated that the methane in that well was from an immature, shallow, thermogenic source.

Most notably, in the cases of GW-3,- $3 a$ and $-3 b$ and GW-8,- $8 a$ and $-8 \mathrm{~b}$, stimulation of the gas wells occurred after elevated methane levels were observed in nearby water wells, indicating that hydraulic fracturing of those wells was not a factor in methane migration at those sites. GW-4, however, about the same distance from WW-H and $-\mathrm{I}$ as GW-3/3a/3b, was stimulated prior to the initial measurements of methane concentration in those water wells. GW-3/3a/3b, however, are much closer to WW-F and -G than GW-4; a portion (15 m) of the annular space of GW-3 was open to shallow glacial till sediments; and there were multiple gas shows in GW-3a, while there were none in GW-4. In addition, WW-J is the closest $(159 \mathrm{~m})$ water well to GW-4 and was unaffected by its activity. These factors appear to favor $\mathrm{GW}-3 / \mathrm{a} / \mathrm{b}$ as the source of methane migrated to wells WW-F, -G, -H and -I.

Various house wells had methane concentrations that declined rapidly to zero or near zero $\mathrm{mg} / \mathrm{L}$. Two cases (WW-H and -I) were likely and five others (WW-B, -E, -L, -Q and -R) were probably related to venting of gas production wells. Five (WW-B, -C, -D, -M and -N) had levels that varied from $0-5$ to 18-39 $\mathrm{mg} / \mathrm{L}$ and one other (WW-G) had concentrations that varied from $20-30$ to $40-60 \mathrm{mg} / \mathrm{L}$. Of those six wells, one home was not a primary residence, and five were provided with potable and bulk water, an aeration treatment system was installed, the well was replaced, or a combination of these actions. In these last cases, the methane levels near zero were probably related to non-use from the water wells. The elevated levels were probably due to withdrawals from water wells, either for outdoor or other non-potable uses, while potable water may also have been supplied by the operator. In those cases, the high methane levels occurred throughout the year, but most often during summer, when demand is high, and mid-winter months, when frozen ground may form a barrier trapping methane gases.

All of the five samples collected in 2009 were from wells in the Burdick Creek basin and each had a thermogenic methane signature. Of the 12 samples collected in 2010, all had thermogenic isotopic signatures; however, three in the Meshoppen Creek basin had C1:C2 ratios $>2,500$, suggesting they had biogenic components. Two (WW-P and -R) were estimated to have originated in the Brailler Formation at depths of 1,000-1,500 m. The third (WW-M) appears to have originated in Catskill/Lochhaven Formation at a depth $<1,000 \mathrm{~m}$.

The methane compositions in nine of the 10 samples collected in 2012 appear to have been altered. The ones with the greatest enrichment (WW-B, WW-J and, possibly WW-C) or depletion (WW-F) had $\mathrm{C} 1: \mathrm{C} 2$ ratios that increased by 66 to $122 \%$ and were from sites where remediation was successful. There is no evidence of enrichment or depletion of the methane in the 2009 samples. At the sites where samples were only collected after remediation (WW-K and WW-L), the C1:C2 ratios were relatively unchanged. At sites with pre- and postremediation samples (WW-E, WW-H and WW-I) and where remediation was either partially successful or unsuccessful, the changes in the $\mathrm{C} 1: \mathrm{C} 2$ ratios were small. These factors would indicate that the migrated methane in the Burdick Creek basin was not altered; but that there was mixing of different sources and it was naturally occurring methane that was probably affected by the microbial oxidation or methanogenesis.

The composition of one other 2012 sample (WW-P) was also unchanged and that was the well for which the best case could be made that the methane had a natural origin. The last 2012 sample (WW-Q) was enriched and the $\mathrm{C} 1: \mathrm{C} 2$ ratio increased by $80 \%$, and the changes appeared to be due to latetime methane migration.

In the Dimock study area, there are similar patterns of methane distribution in the water wells near individual gas well sites, but not between water wells at different gas well sites. This could be another indicator for detecting methane migration caused by gas well operations. Of the 17 water wells potentially affected by methane migration, 13 were within $442 \mathrm{~m}$ of a gas well, 3 were between 475 and $564 \mathrm{~m}$ of a gas well, and 1 was $785 \mathrm{~m}$ from a gas well.

Generally, squeeze cementing of the wells in this study were conducted at shallow depths, $\leq 457 \mathrm{~m}$ (1,500 feet) and very deep depths, $\geq 1,524 \mathrm{~m}$ (5,000 feet). These depths correspond with the approximate age and depths of migrated methane in the water well samples. GW-2, $-4,-7,-8,-8 \mathrm{a}$ and $-8 \mathrm{~b}$ are still listed as active wells and are possible candidates for additional study.

\section{Conclusions}

The number of water wells in the study area exceeding the hazard limits for methane were much greater than would be expected, based on the regional studies of background levels 
in the surrounding vicinity. Water wells sampled in 2009 had isotopic signatures similar to annular space gases, but were depleted relative to production gases. The significant changes in isotopic parameters that occurred after remediation indicate that migrated methane was not altered, but that different sources were present, both natural and man-induced. What appeared to be altered samples is probably natural methane formed by either microbial oxidation or methanogenesis. All of the samples from water wells in the study had thermogenic methane signatures. Two, however, had $\mathrm{C} 1: \mathrm{C} 2$ ratios typical of biogenic gases, but the methane may have originated at depths of 1,000-1,500 m, suggesting migration of gases with a biogenic component from the deep subsurface.

In the cases of GW- $3 / \mathrm{a} / \mathrm{b}$ and $\mathrm{GW}-8 / \mathrm{a} / \mathrm{b}$, methane migrated to at least two and as many as seven water wells before hydraulic fracturing of those gas wells. For the remaining gas wells, sampling of water wells did not start until after hydraulic fracturing was completed.

Gas well activity appears to have impacted all but one of the house wells in the study area to a lesser or greater degree. The main reason that migration occurred was probably due to uncemented sections of gas wells above the Marcellus Shale being in contact with gas-bearing, but unproductive, formations, with leakage upward by annular cement seals, to below or outside of the protective surface casing, and into the aquifer supplying the residential water wells. There was no evidence of leakage of Marcellus gases due to production casing failures.

Remediation of gas wells by squeeze cementing or plugging procedures was only partially successful; however, providing alternate supplies or treatment of water wells was relatively effective in correcting impacts due to methane migration. Venting of gas wells, while monitoring methane levels in water wells, appears to be a cost-effective method for detecting if methane migration has occurred. Where multiple possible sources of migrated methane may exist, the gas wells should be vented separately.

The results of the present study are site-specific and are not necessarily evidence of a wide-spread regional problem; however, they do provide means of improving the methods for preventing, detecting and mitigating impacts associated with methane migration. The best available practices developed for cementing programs should be utilized when completing a gas well. A work plan should include primary cementation of the entire length of production casing or, as a minimum, sections with unproductive gas shows or flows.

Detailed records related to potential methane migration, including dates of all gas well operations, should be maintained and available to all responsible governmental agencies, even if not required by statute or regulation. These records should include those for drilling, cementation (primary and squeeze), completion, venting, hydraulic fracturing, water sampling and remediation of gas and water wells. A consistent method for identifying gas and water wells is needed in order to compare or reproduce the results of various investigations.

The best method for identifying methane migration is the sampling of water wells for molecular and isotope analyses, before and after gas well construction and hydraulic fracturing, during venting of gas wells and after remediation of gas wells. The results should be compared to analyses of gas well mud, annular space and production gases. Significant changes in compositions of the water wells can be used to determine if multiple sources are present or migrated methane has been altered, and the effectiveness of remediation programs.

Acknowledgements Dr. Malcolm Field greatly assisted during the final preparation of the manuscript. The editor, Dr. Elizabeth Screaton, an anonymous associate editor, Dr. Stuart Gilfillan and a second reviewer (anonymous), and the technical editor, Ms. Sue Duncan, provided many useful comments and suggestions that greatly improved the manuscript's content and organization. Ms. Phung Pham brought the issue of the methane migration to the author's attention and participated in early discussions about the previous studies in the Dimock area.

Open Access This article is distributed under the terms of the Creative Commons Attribution 4.0 International License (http:// creativecommons.org/licenses/by/4.0/), which permits unrestricted use, distribution, and reproduction in any medium, provided you give appropriate credit to the original author(s) and the source, provide a link to the Creative Commons license, and indicate if changes were made.

\section{References}

Baldassare FJ, McCaffrey MA, Harper JA (2014) A geochemical context for stray gas investigations in the northern Appalachian Basin: implications of analyses of natural gases from Neogene- through Devonian-age strata. AAPG Bull 98(2):341-372

Cabot Oil \& Gas Corporation (2011) DEP meeting on October 11, 2011 (Data presentation to PA DEP). http://www.cabotog.com/pdfs/Data Presentation_DEP.pdf. Accessed 19 May 2014

Damascus Citizens for Sustainability (2009) PA DEP data for Dimock, Pennsylvania. http://www.damascuscitizensforsustainability.org/ dep-data-for-dimock-pa. Accessed 24 April 2014

Eltschlager KK, Hawkins JW, Ehler WC, Baldassare F (2001) Technical measures for the investigation and mitigation of fugitive methane hazards in areas of coal mining. US Dept of the Interior, Office of Surface Mining Reclamation and Enforcement, Pittsburgh, PA

Jackson RB (2014) The integrity of oil and gas wells. Proc Natl Acad Sci USA 111(30):10902-10903

Jackson RB, Vengosh A, Darrah TH, Warner NR, Down A, Poreda RJ, Osborn SG, Zhao K, Karr JD (2013) Increased stray gas abundance in a subset of drinking water wells near Marcellus shale gas extraction. Proc Natl Acad Sci USA 110(28):11250-11255

Kotelnikova S (2002) Microbial production and oxidation of methane in deep subsurface. Earth Sci Rev 58:367-395

Le Mer J, Roger P (2001) Production, oxidation, emission and consumption of methane by soils: a review. Eur J Soil Biol 37(1):25-50

Molofsky LJ, Connor JA, Farhat SK, Wylie AS, Wagner T (2011) Methane in Pennsylvania water wells unrelated to Marcellus shale fracturing. Oil Gas J 109(49):54-93 
Molofsky LJ, Connor JA, Wylie AS, Wagner T, Farhat SK (2013) Evaluation of methane sources in groundwater in northeastern Pennsylvania. Ground Water 51(3):333-349

Osborn SG, Vengosh A, Warner NR, Jackson RB (2011) Methane contamination of drinking water accompanying gas-well drilling and hydraulic fracturing. Proc Natl Acad Sci USA 108(20):8172-8176

Pennsylvania Dept. of Environmental Protection (2009) PA oil and gas mapping website. http://www.depgis.state.pa.us/ PaOilAndGasMapping. Accessed 27 October 2014

Scheutz C, Kjeldsen P (2004) Environmental factors influencing attenuation of methane and hydrochlorofluorocarbons in landfill cover soils. J Environ Qual 33(1):72-79

Schoell M (1980) The hydrogen and carbon isotropic composition of methane from natural gases of various origins. Geochim Cosmochim Acta 44:649-662
Schoell M (1983) Genetic characterization of natural gases. AAPG Bull 67:2225-2238

Tsunomori F, Notsu K (2008) Simultaneous monitoring of gas concentration and groundwater level at the Omaezaki 500-m well, central Japan: spike-like concentration change of methane. Geochem J 42(1):85-91

United States Environmental Protection Agency (2012) Dimock residential groundwater site, Dimock PA-USEPA region III (Molecular and isotopic data). http://www.epaosc.org/site/doc_list.aspx?site_id= 7555. Accessed 6 April 2014

Watson RW (2010) White paper and full report. Cabot Oil \& Gas Corporation, Houston, TX. http://www.cabotog.com/pdfs/Data Presentation_DEP.pdf. Accessed 7 May 2104

Whiticar MJ (1999) Carbon and hydrogen isotope systematics of bacterial formation and oxidation of methane. Chem Geol 161(1):291-314 